\title{
Structure of Poduromorpha (Collembola) communities in "restinga" environments in Brazil
}

\author{
Liliane Henriques Fernandes( ${ }^{(1)}$, Jorge Luiz Nessimian ${ }^{(2)}$ and Maria Cleide de Mendonça(1)
}

\begin{abstract}
${ }^{(1)}$ Museu Nacional, Departamento de Entomologia, Quinta da Boa Vista, São Cristóvão, CEP 20940-040 Rio de Janeiro, RJ, Brazil. E-mail: lilianefer@gmail.com, mcleide@acd.ufrj.br (2)Universidade Federal do Rio de Janeiro, Instituto de Biologia, Departamento de Zoologia, Laboratório de Entomologia, Caixa Postal 68044, CEP 21944-970 Rio de Janeiro, RJ, Brazil. E-mail: nessimia@acd.ufrj.br
\end{abstract}

\begin{abstract}
The objectives of this work were to evaluate the richness and diversity of the Poduromorpha fauna in two biotopes in Restinga de Maricá, RJ, Brazil, to identify the characteristic species of each biotope and to determine the relationships between the community structure and the abiotic environmental parameters. Representatives of the Poduromorpha (Collembola) order were studied under an ecological viewpoint in halophyte-psammophyte vegetation and foredune zone in preserved areas of Restinga de Maricá, a sand dune environment in the state of Rio de Janeiro, Brazil. The foredune zone showed the highest diversity, richness and equitability of springtail species. Differences in the fundamental, accessory and accidental species in each environment were encountered. Paraxenylla piloua was found to be an indicator species of the halophyte-psammophyte vegetation, while Friesea reducta, Pseudachorutes difficilis and Xenylla maritima were indicators of the foredune zone. The canonical correspondence analysis indicated $\mathrm{pH}$, organic matter content and soil humidity as the most important factors influencing the spatiotemporal distribution of the species.
\end{abstract}

Index terms: bioindicator, ecology, littoral, springtails.

\section{Estrutura de comunidades de Poduromorpha (Collembola) em áreas de restinga}

\begin{abstract}
Resumo - Os objetivos deste trabalho foram avaliar a riqueza e a diversidade da fauna de Poduromorpha em dois biótopos na Restinga de Maricá, RJ, identificar as espécies características de cada biótopo e determinar as relações da estrutura da comunidade com parâmetros ambientais abióticos. Representantes da ordem Poduromorpha (Collembola) foram estudados do ponto de vista ecológico nos ambientes de vegetação halófila-psamófila reptante e de primeiro cordão arenoso em áreas preservadas da Restinga de Maricá, localizada no Estado do Rio de Janeiro, Brasil. Os maiores valores de diversidade, riqueza e equitabilidade de espécies de colêmbolos foram observados no ambiente de primeiro cordão arenoso. Foram encontradas diferenças nas espécies fundamentais, acessórias e acidentais nos ambientes amostrados. Paraxenylla piloua atuou como indicadora de ambiente da vegetação halófila-psamófila reptante, ao passo que Friesea reducta, Pseudachorutes difficilis e Xenylla maritima mostraram-se indicadoras de ambiente de primeiro cordão arenoso. A análise de correspondência canônica mostrou que os fatores mais importantes na distribuição espaço-temporal das espécies foram $\mathrm{pH}$, conteúdo de matéria orgânica e umidade do solo.
\end{abstract}

Termos para indexação: bioindicador, ecologia, litoral, colêmbolos.

\section{Introduction}

Collembola (springtails) have been used in ecological research due to their great diversity of compatible habitats and their rapid reaction to environmental variations. Together with mites (Acari), they can represent up to $98 \%$ of the total mesofauna in soils (Miranda-Rangel \& Palacios-Vargas, 1992; Eaton et al., 2004).

Many papers have been published on Collembola taxonomy, but ecological research on springtails is also extensive and has been growing. In the last 30 years, data on springtail fauna and biogeography, population dynamics and species composition in temperate regions has increased significantly (Pozo, 1986; Souza et al., 2003). However, only after 1985 the littoral springtails have received more attention by several experts with emphasis on taxonomical studies (Thibaud, 2002, 2004), biodiversity research (Thibaud \& Christian, 1997) and community structure (Ehrnsberger et al., 1997). In Brazil, these studies are still scarce, especially those related to the littoral Collembola, with only a few species records so far. In Restinga de Maricá, RJ, 
the first study concerning the littoral Collembola was performed by Vallejo \& Vallejo (1981), and only after a long period were new taxonomic and biodiversity studies performed (Mendonça \& Arlé, 1992; Mendonça \& Fernandes, 1997; Thibaud \& Palacios-Vargas, 1999; Fernandes \& Mendonça, 2002, 2004, 2007).

The restingas were chosen as the object of this study not only because of the few number of known species in this habitat, but also because it is a highly endangered ecosystem of the Mata Atlântica biome, one of the world's hotspots of biodiversity. The main threats to this ecosystem are urbanization and pollution, enhanced by real estate speculation and population pressure on coastal environments (removal of sand and decorative plants, lumber extraction, forest fires and litter deposits). The damage to the biological and landscape components is irreversible and puts a valuable genetic patrimony at risk.

The objectives of this study were to evaluate the richness and diversity of the Poduromorpha fauna in two biotopes in Restinga de Maricá, RJ, to identify the characteristic species of each biotope and to determine the relationships between the community structure and the abiotic environmental parameters.

\section{Materials and Methods}

The study was carried out at Área de Proteção Ambiental (APA) de Maricá $\left(22^{\circ} 52^{\prime}-22^{\circ} 54^{\prime} \mathrm{S}\right.$ and $42^{\circ} 48^{\prime}-42^{\circ} 54^{\prime} \mathrm{W}$ ), which occupies a total area of $8.3 \mathrm{~km}^{2}$. Two distinct areas were selected in two districts of the Maricá county: Itaipuaçu and Maricá. These areas were separated in two biotopes: halophyte-psammophyte vegetation and foredune zone (Figure 1). The halophyte-psammophyte vegetation area was located above the highest tide but still subjected to ocean water reflux. This vegetation consisted of creeping and herbal plants capable of living in high salinity, direct exposure to solar radiation and windy conditions. In this nutrient-poor biotope, the typical plant species found were: Alternanthera maritima (Mart.) A. St.-Hil. (Amaranthaceae), Blutaparon portulacoides (A. St.-Hil.) Mears (Amaranthaceae), Sporobolus virginicus (L.) Kunth (Poaceae), Mariscus pedunculatus (R. Br.) T. Koyama (Cyperaceae), Ipomoea pes-caprae (L.) Sweet and Ipomoea imperati (Valhl) Griseg (Convolvulaceae) (Silva \& Oliveira, 1989). The foredune zone had an irregular shape and was covered by small shrubs, protected by the sand dunes, which formed some tangled areas of difficult access (Silva \& Oliveira, 1989). This biotope was more intensively affected by soil salinity, substrate mobility and by the action of the winds than by the surrounding vegetation (Silva \& Somner, 1984). Typical plant species found in this biotope were: Eugenia uniflora L. (Myrtaceae), Schinus terebinthifolius Raddi (Anacardiaceae), Clusia lanceolata Cambess., Clusia fluminensis Planch. \& Triana (Clusiaceae), Cereus fernambucensis Lem. (Cactaceae), Allagoptera arenaria (Gomes) Kuntze (Arecaceae) and Neoregelia cruenta (Graham) L. B. Sm. (Bromeliaceae) (Silva \& Oliveira, 1989).

Samples were collected during the rainy (summer) and dry (winter) seasons, in December/January and June/July of 2003 respectively. From each area and biotope, four soil/litter samples were taken and the soil

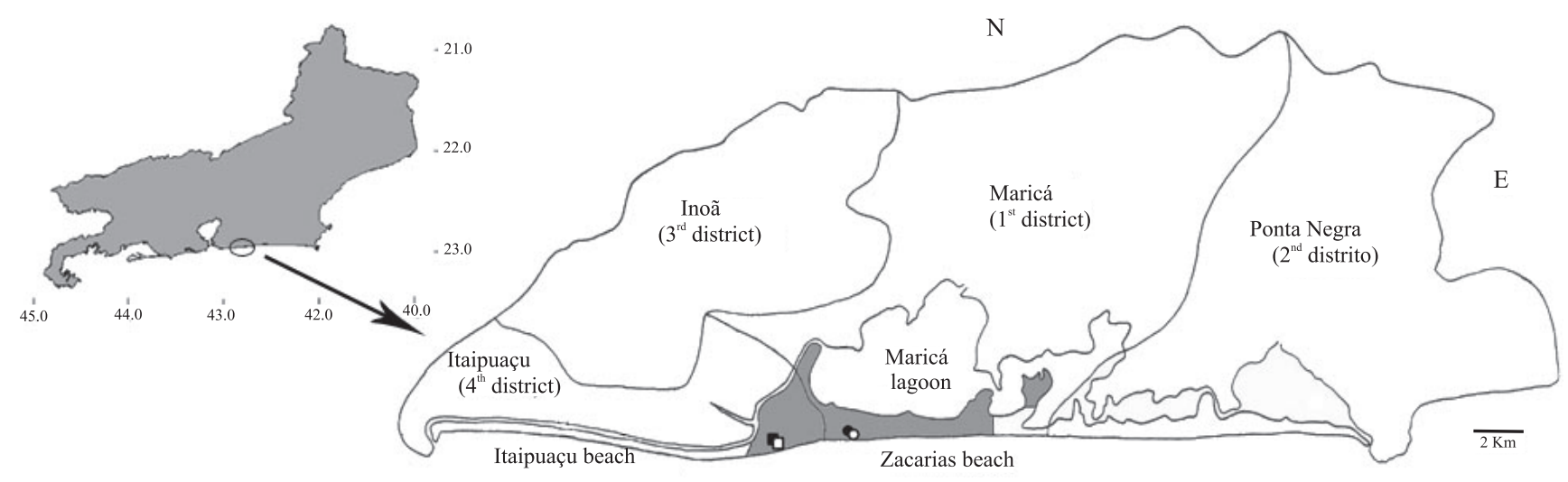

Figure 1. Map of the state of Rio de Janeiro showing the city of Maricá, its districts, the APA of Maricá (in gray) and the sampling sites: Itaipuaçu APA, halophyte-psammophyte vegetation (ם IAA); Itaipuaçu APA, foredune zone (匹 IAB); Maricá APA, halophyte-psammophyte vegetation( $\circ$ MAA); Maricá APA, foredune zone $(\bullet$ MAB). 
temperature was recorded using a soil thermometer inserted into the soil for $3 \mathrm{~min}$. Soil samples were taken to assess soil moisture, organic matter, carbon, nitrogen, soil $\mathrm{pH}$, available phosphorus, aluminum, hydrogen and base content $(\mathrm{Ca}$, $\mathrm{Mg}, \mathrm{K}, \mathrm{Na}$ ). Soil analyses were performed at Laboratório de Água, Solos e Plantas (LASP) of Embrapa Solos, Rio de Janeiro, RJ, Brazil.

Differences in community composition of each area were evaluated using the following indices: diversity (Shannon-Wiener), richness (Margalef) and evenness (Pielou) (Ludwig \& Reynolds, 1988). The Tukey honest test was used to verify the relation between abiotic parameters and the sampled biotopes. The indicator species test (Dufrene \& Legendre, 1997) was applied to verify which species were characteristic of each biotope. The results were submitted to the Monte Carlo test with 1,000 permutations to verify the significance, for which values of $\mathrm{p}<0.05$ were accepted.

Canonical correspondence analysis (Ludwig \& Reynolds, 1988) was performed in order to detect and visualize the relationships between taxa and abiotic parameters. In this analysis, two data matrices were used: sampling points versus taxa and sampling points versus abiotic parameters. The first data matrix was transformed into $\log (\mathrm{x}+1)$ and the second data matrix into $(\mathrm{xi}-\overline{\mathrm{x}}) / \sigma$, where $\mathrm{xi}=$ observed value; $\overline{\mathrm{x}}=$ mean and $\sigma=$ standard deviation. The programs used in the statistical analysis were PC-ORD for Windows (Mccune \& Mefford, 1999), Statistica for Windows (Statsoft, 1997) and DivEs (diversidade de espécies) (Rodrigues, 2005).

\section{Results and Discussion}

Significant differences between the biotopes were found in relation to tiritable acidity, base saturation, $\mathrm{Al}$ saturation, $\mathrm{pH}$, carbon, nitrogen, organic matter and soil temperature (Table 1). According to Hay \& Lacerda (1984), in the Restinga de Barra de Maricá the soil becomes more acid and there is an increase in the organic matter content and cation exchange capacity until it becomes constant at approximately 100 meters from the halophyte-psammophyte vegetation, which is in agreement with the present data. The foredune zone biotope had high cation exchange capacity due to the high organic matter concentration and Al saturation, as also observed by Hay \& Lacerda (1984). Soil temperature and moisture were lower and higher, respectively, in the foredune zone biotope, indicating more agreeable conditions for the soil fauna in this environment.

Among the 15 species found, the most abundant were Xenylla welchi, Xenylla maritima and Paraxenylla piloua: all of them belong to the family Hypogastruridae (Table 2). The species $X$. welchi, $X$. maritima, Mesaphorura amazonica, Mesaphorura yosii and Brachystomella ceciliae had wide distributions and occurred in almost all sampled areas. The species $P$. piloua, Friesea mirabilis and Friesea claviseta were restricted to the halophyte-psammophyte vegetation. Other species, such as Friesea reducta, Pseudachorutes difficilis, Hylaeanura infima, Brachystomella agrosa and Maricaella duna, were restricted to the foredune zone.

Table 1. Mean \pm standard deviation of soil physicochemical parameters of the sample sites halophyte-psammophyte vegetation (HP) and foredune zone (FD).

\begin{tabular}{|c|c|c|c|c|c|}
\hline \multirow[t]{2}{*}{ Parameter } & \multicolumn{2}{|c|}{ Itaipuaçu } & \multicolumn{2}{|c|}{ Maricá } & \multirow[t]{2}{*}{$\mathrm{p}^{(1)}$} \\
\hline & $\mathrm{HP}$ & FD & $\mathrm{HP}$ & FD & \\
\hline $\mathrm{Ca}^{2+}\left(\mathrm{cmol}_{\mathrm{c}} \mathrm{kg}^{-1}\right)$ & $0.53 \pm 2.1$ & $0.56 \pm 1.1$ & $0.00 \pm 0.0$ & $0.16 \pm 0.3$ & ns \\
\hline $\mathrm{Mg}^{2+}\left(\mathrm{cmol}_{\mathrm{c}} \mathrm{kg}^{-1}\right)$ & $0.80 \pm 1.4$ & $0.58 \pm 0.4$ & $0.48 \pm 0.2$ & $0.56 \pm 0.2$ & ns \\
\hline $\mathrm{K}^{+}\left(\mathrm{cmol}_{\mathrm{c}} \mathrm{kg}^{-1}\right)$ & $0.01 \pm 0.0$ & $0.02 \pm 0.0$ & $0.02 \pm 0.0$ & $0.03 \pm 0.0$ & ns \\
\hline $\mathrm{Na}^{+}\left(\mathrm{cmol}_{\mathrm{c}} \mathrm{kg}^{-1}\right)$ & $0.08 \pm 0.1$ & $0.03 \pm 0.0$ & $0.12 \pm 0.2$ & $0.08 \pm 0.1$ & ns \\
\hline Sum of bases $\left(\mathrm{cmol}_{\mathrm{c}} \mathrm{kg}^{-1}\right)$ & $1.41 \pm 3.5$ & $1.18 \pm 1.5$ & $0.61 \pm 0.3$ & $0.83 \pm 0.4$ & ns \\
\hline $\mathrm{Al}^{3+}\left(\mathrm{cmol}_{\mathrm{c}} \mathrm{kg}^{-1}\right)$ & $0.03 \pm 0.1$ & $0.06 \pm 0.1$ & $0.01 \pm 0.0$ & $0.02 \pm 0.0$ & ns \\
\hline $\mathrm{H}+\mathrm{Al}\left(\mathrm{cmol}_{\mathrm{c}} \mathrm{kg}^{-1}\right)$ & $0.10 \pm 0.1$ & $0.96 \pm 1.0$ & $0.05 \pm 0.1$ & $0.96 \pm 0.6$ & 0.0001 \\
\hline $\operatorname{CEC}\left(\mathrm{cmol}_{\mathrm{c}} \mathrm{kg}^{-1}\right)$ & $1.54 \pm 3.5$ & $2.20 \pm 2.5$ & $0.68 \pm 0.4$ & $1.80 \pm 0.7$ & ns \\
\hline Base saturation (\%) & $85.56 \pm 15.1$ & $50.94 \pm 12.1$ & $93.06 \pm 11.0$ & $48.13 \pm 15.0$ & 0.0001 \\
\hline $\mathrm{m}(\%)$ & $0.19 \pm 7.0$ & $5.63 \pm 7.8$ & $1.44 \pm 4.0$ & $1.81 \pm 3.9$ & 0.02 \\
\hline Available $\mathrm{P}\left(\mathrm{mg} \mathrm{kg}^{-1}\right)$ & $4.69 \pm 27.6$ & $3.13 \pm 3.2$ & $3.13 \pm 1.0$ & $3.38 \pm 2.8$ & $\mathrm{~ns}$ \\
\hline $\mathrm{pH}$ - water & $6.94 \pm 0.6$ & $5.38 \pm 0.3$ & $6.85 \pm 0.5$ & $5.56 \pm 0.3$ & 0.0001 \\
\hline $\mathrm{pH}-\mathrm{KCl}$ & $6.40 \pm 0.7$ & $4.46 \pm 0.4$ & $6.35 \pm 0.6$ & $4.68 \pm 0.4$ & 0.0001 \\
\hline $\mathrm{C}\left(\mathrm{g} \mathrm{kg}^{-1}\right)$ & $0.86 \pm 0.4$ & $3.94 \pm 4.4$ & $0.63 \pm 0.3$ & $4.89 \pm 2.9$ & 0.0001 \\
\hline $\mathrm{N}\left(\mathrm{g} \mathrm{kg}^{-1}\right)$ & $0.11 \pm 0.0$ & $0.38 \pm 0.5$ & $0.11 \pm 0.0$ & $0.31 \pm 0.1$ & 0.001 \\
\hline Organic matter $\left(\mathrm{g} \mathrm{kg}^{-1}\right)$ & $1.49 \pm 18.5$ & $6.80 \pm 7.6$ & $1.07 \pm 0.6$ & $8.43 \pm 4.9$ & 0.0001 \\
\hline Soil moisture $(\%)$ & $2 \pm 0.0$ & $3 \pm 0.0$ & $2 \pm 0.0$ & $3 \pm 0.0$ & ns \\
\hline Soil temperature $\left({ }^{\circ} \mathrm{C}\right)$ & $26.72 \pm 2.6$ & $25.31 \pm 2.2$ & $28.56 \pm 3.7$ & $26.56 \pm 2.2$ & 0.03 \\
\hline
\end{tabular}

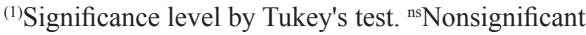


Higher values of diversity, richness and evenness were observed in the foredune zone (Table 2), probably due to the higher organic matter content and soil moisture, which promoted greater plant growth. Therefore, this biotope appears to be more stable and more conducive to the development of soil fauna.

Paraxenylla piloua, described from a New Caledonian sand beach, was found in the Restinga de Maricá only in the halophyte-psammophyte vegetation, where it was considered an indicator species $(\mathrm{p}=0.001$, Table 3$)$. On the other hand, $X$. maritima, F. reducta and $P$. difficilis were indicator species of the foredune zone. All three species were previously recorded by Fernandes \& Mendonça
(2004) for Restinga de Itaipuaçu. The restricted appearance of $F$. reducta in this biotope diverges from the generalist condition for this species reported in the literature (Thibaud \& Massoud, 1983). Xenylla maritima was the most abundant and frequent among the Poduromorpha species, confirming its resistance to xerophitic conditions, as found by Arbea \& Jordana (1991).

Canonical correspondence analysis has been widely used to assess the relationships between springtail species and soil parameters (Hasegawa, 2001; Sousa et al., 2003; Gómez-Anaya \& Palacios-Vargas, 2004). In the present study, the canonical correspondenceanalysis revealedahighly significant difference in the community structure (Table 4).

Table 2. Total abundance of the Poduromorpha species, diversity, richness and evenness indices in the biotopes halophyte-psammophyte vegetation (HP) and foredune zone (FD).

\begin{tabular}{|c|c|c|c|c|}
\hline \multirow[t]{2}{*}{ Taxa } & \multicolumn{2}{|c|}{ Itaipuaçu } & \multicolumn{2}{|c|}{ Maricá } \\
\hline & $\mathrm{HP}$ & FD & $\mathrm{HP}$ & FD \\
\hline Austrogastrura travassosi (Arlé, 1939) & - & - & 1 & - \\
\hline Brachystomella agrosa Wray, 1953 & - & 8 & - & - \\
\hline Brachystomella ceciliae Fernandes \& Mendonça, 2004 & - & 12 & 2 & 9 \\
\hline Friesea claviseta Axelson, 1900 & - & - & 1 & - \\
\hline Friesea mirabilis (Tullberg, 1871) & - & - & 1 & - \\
\hline Friesea reducta Denis, 1931 & - & 39 & - & 52 \\
\hline Hylaeanura infima (Arlé, 1959) & - & - & - & 1 \\
\hline Maricaella duna Mendonça \& Fernandes, 1997 & - & 2 & - & - \\
\hline Mesaphorura amazonica Oliveira \& Thibaud, 1992 & - & 3 & 30 & 1 \\
\hline Mesaphorura yosii Rusek, 1971 & 1 & 5 & - & 5 \\
\hline Paraxenylla piloua Thibaud \& Weiner, 1997 & 106 & - & 99 & - \\
\hline Pseudachorutes difficilis Denis, 1931 & - & 3 & - & 8 \\
\hline Rapoportella pitomboi Mendonça \& Fernandes, 1995 & 1 & 1 & - & - \\
\hline Xenylla maritima Tullberg 1869 & 5 & 108 & - & 114 \\
\hline Xenylla welchi Folsom, 1916 & 24 & 427 & 4 & 311 \\
\hline Total & 137 & 608 & 138 & 501 \\
\hline Number of taxa $\mathrm{S}$ (species richness) & 5 & 10 & 7 & 8 \\
\hline Diversity (Shannon-Wiener) & 0.30 & 0.43 & 0.36 & 0.47 \\
\hline Richness (Margalef) & 1.87 & 3.23 & 2.80 & 2.59 \\
\hline Evenness (Pielou) & 0.22 & 0.22 & 0.20 & 0.26 \\
\hline
\end{tabular}

Table 3. Indicator species test of halophyte-psammophyte vegetation (HP) and foredune zone (FD) in Restinga de Maricá.

\begin{tabular}{lccrc}
\hline Taxa & Ind. val. (\%) & HP & FD & $\mathrm{p}^{(1)}$ \\
\hline Austrogastrura travassosi & 8.3 & 8 & 0 & $\mathrm{~ns}$ \\
Brachystomella agrosa & 9.1 & 0 & 9 & $\mathrm{~ns}$ \\
Brachystomella ceciliae & 38.7 & 1 & 39 & $\mathrm{~ns}$ \\
Friesea claviseta & 8.3 & 8 & 0 & $\mathrm{~ns}$ \\
Friesea mirabilis & 8.3 & 8 & 0 & $\mathrm{~ns}$ \\
Friesea reducta & 59.1 & 0 & 59 & 0.005 \\
Hylaeanura infima & 4.5 & 0 & 5 & $\mathrm{~ns}$ \\
Maricaella duna & 9.1 & 0 & 9 & $\mathrm{~ns}$ \\
Mesaphorura amazonica & 7.8 & 8 & 1 & $\mathrm{~ns}$ \\
Mesaphorura yosii & 26.9 & 1 & 27 & $\mathrm{~ns}$ \\
Paraxenylla piloua & 75.0 & 75 & 0 & 0.001 \\
Pseudachorutes difficilis & 36.4 & 0 & 36 & 0.037 \\
Rapoportella pitomboi & 5.4 & 5 & 2 & $\mathrm{~ns}$ \\
Xenylla maritima & 52.4 & 0 & 52 & 0.020 \\
Xenylla welchi & 55.2 & 2 & 55 & $\mathrm{~ns}$ \\
\hline
\end{tabular}

${ }^{(1)}$ Significance level by Tukey's test. ${ }^{\text {ns}}$ Nonsignificant.
Table 4. Correlation coefficients between soil parameters and the ordination axes, and summary of canonical correspondence analysis.

\begin{tabular}{lrcc}
\hline Variable & Axis 1 & Axis 2 & Axis 3 \\
\hline $\mathrm{Ca}$ & -0.206 & -0.336 & 0.167 \\
$\mathrm{Mg}$ & -0.205 & 0.037 & 0.292 \\
$\mathrm{~K}$ & 0.027 & -0.128 & 0.163 \\
$\mathrm{Na}$ & 0.297 & -0.114 & 0.184 \\
$\mathrm{Al}$ & -0.110 & 0.436 & 0.122 \\
$\mathrm{H}+\mathrm{Al}$ & -0.580 & -0.045 & 0.157 \\
$\mathrm{P}$ & 0.032 & -0.132 & 0.011 \\
$\mathrm{pH}$ & 0.863 & -0.131 & -0.001 \\
Carbon & -0.550 & -0.052 & 0.124 \\
Organic matter & -0.551 & -0.050 & 0.125 \\
Nitrogen & -0.219 & 0.136 & -0.042 \\
Soil moisture & -0.149 & 0.328 & 0.129 \\
Soil temperature & 0.065 & 0.134 & -0.250 \\
\hline Eigenvalue & 0.668 & 0.245 & 0.201 \\
Variance (\% of cumulative variance explained) & 21.8 & 29.8 & 36.4 \\
Pearson correlation, species x environment & 0.895 & 0.889 & 0.663 \\
Kendall correlation, species x environment & 0.567 & 0.470 & 0.322 \\
\hline
\end{tabular}


On axis 1, representing $21.8 \%$ of the total variability, the factor that mostly influenced the distribution of the species was soil $\mathrm{pH}$, which separated two groups of species (Figure 2). On therightside of the biplot, F. mirabilis, P.piloua, Austrogastrura travassosi and Rapoportella pitomboi were associated with halophyte-psammophyte vegetation, where the soil $\mathrm{pH}$ values are relatively high. On the opposite side, M. amazonica, M. yosii, X. welchi, X. maritima, B. ceciliae,
B. agrosa, $M$. duna, F. reducta and $P$. difficilis were linked to a more acid soil $\mathrm{pH}$, as it was found in the foredune zone biotope. On axis two, which represented $29.8 \%$ of the total variability, the factors that mostly influenced the distribution of species were soil moisture and Al concentration (Table 4).

The present results agree with the ones of Thibaud \& Christian (1989), who also found a significant

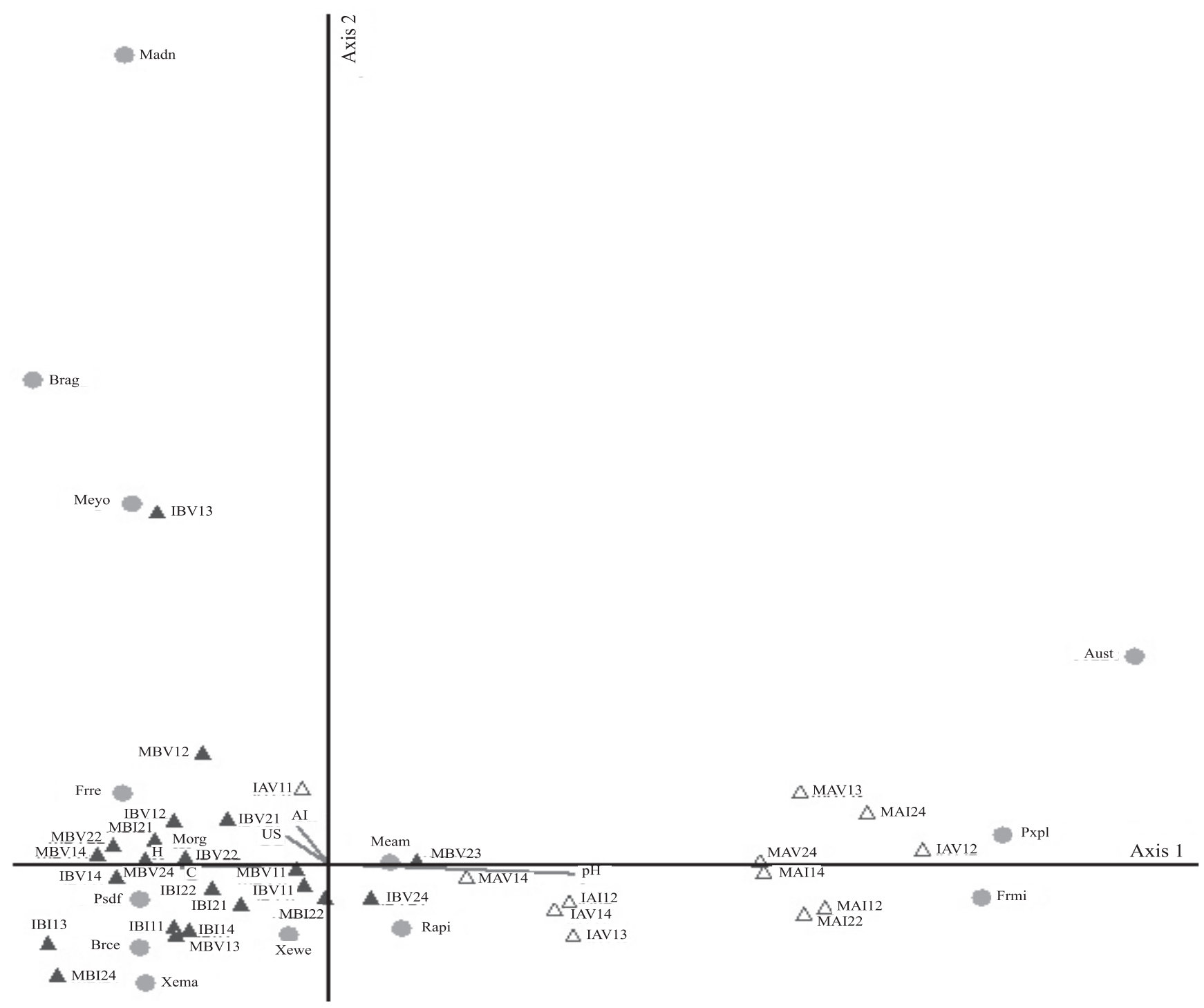

Figure 2. Canonical correspondence analysis based on species versus samples versus abiotic parameters. $\Delta$, halophytepsammophyte vegetation; $\boldsymbol{\Lambda}$, foredune zone; $\bigcirc$, species. Species: Aust, Austrogastrura travassosi; Brag, Brachystomella agrosa; Brce, Brachystomella ceciliae; Frmi, Friesea mirabilis; Frre, Friesea reducta; Madn, Maricaella duna; Meam, Mesaphorura amazonica; Meyo, Mesaphorura yosii; Psdf, Pseudachorutes difficilis; Pxpl, Paraxenylla piloua; Rapi, Rapoportella pitomboi; Xema, Xenylla maritima; Xewe, Xenylla welchi. Sampling points: IA, Itaipuaçu, halophyte-psammophyte vegetation; IB, Itaipuaçu, foredune zone; MA, Maricá, halophyte-psammophyte vegetation; MB, Maricá, foredune zone; V1, rain season 1 (January); V2, rain season 2 (December); I1, dry season 1 (June); I2, dry season 2 (July). 
relationship between springtail distribution and species composition according to soil $\mathrm{pH}$ in Mediterranean littoral sands. Pozo (1986) and Cutz-Pool et al. (2003) also identified the soil $\mathrm{pH}$ as one of the most important factors affecting springtail species distribution, favoring some species and causing the most sensitive ones to disappear. Collembola distribution in acid, neutral or alkaline soils can also be affected by human-induced changes to soil $\mathrm{pH}$, altering their ecological needs (Salmon et al., 2002).

Springtails are very sensitive to and strongly affected by soil moisture changes (Pozo, 1986; Miranda-Rangel \& Palacios-Vargas, 1992). The present study also showed the importance of soil moisture for the composition and structure of the springtail communities in the sampled biotopes.

The use of indicator species to identify vegetation structure and soil conditions may be useful in the assessment of ecosystem conservation and recovery programs. Further research is necessary to evaluate the role and use of soil fauna (such as Collembola) as indicators of the ecological conditions and quality of "restinga" environments.

\section{Conclusions}

1. Collembola species composition is affected by biotope in Restinga de Maricá.

2. The Collembola community is influenced by soil $\mathrm{pH}$, humidity and organic matter content.

3. InRestinga de Maricá, Collembola species respond, in different ways, to the same abiotic parameters.

\section{Acknowledgements}

To Conselho Nacional de Desenvolvimento Científico e Tecnológico and Fundação de Amparo à Pesquisa do Estado do Rio de Janeiro, for the financial support; to Eduardo Assis Abrantes, for the help with the English translation.

\section{References}

ARBEA, J.I.; JORDANA, R. Colémbolos de Navarra (Norte de la Península Ibérica). I. Orden Poduromorpha (Collembola). Publicaciones de Biología de la Universidad de Navarra, Serie Zoologica, v.22, p.1-149, 1991.

CUTZ-POOL, L.Q.; PALACIOS-VARGAS, J.G.; VÁZQUEZ, M.M. Comparación de algunos aspectos ecológicos de Collembola en cuatro asociaciones vegetales de Noh-Bec, Quintana Roo, México. Folia Entomologica Mexicana, v.21, p.91-101, 2003.

DUFRENE, M.; LEGENDRE, P. Species assemblages and indicator species: the need for a flexible asymmetrical approach. Ecological Monographs, v.67, p.345-366, 1997.

EATON, R.J.; BARBERCHECK, M.; BUFORD, M.; SMITH, W. Effects of organic matter removal, soil compaction, and vegetation control on Collembolan populations. Pedobiologia, v.48, p.121-128, 2004.

EHRNSBERGER, R.; STERZYNSKA, M.; SZEPTYCKI, A. Apterygota of a North Sea salt marsh - community structure and vertical distribution. Pedobiologia, v.41, p.123-130, 1997.

FERNANDES, L.H.; MENDONÇA, M.C. de. Collembola Poduromorpha de áreas preservadas e impactadas do litoral sudeste do Brasil. Revista Brasileira de Zoologia, v.24, p.777-785, 2007.

FERNANDES, L.H.; MENDONÇA, M.C. de. Collembola Poduromorpha do litoral de Maricá, Rio de Janeiro, Brasil. Revista Brasileira de Zoologia, v.21, p.15-25, 2004.

FERNANDES, L.H.; MENDONÇA, M.C. de. Duas novas espécies de Pseudachorutinae (Collembola, Neanuridae) do Brasil. Boletim do Museu Nacional, Nova Série, Zoologia, v.496, p.1-8, 2002.

GÓMEZ-ANAYA, J.A.; PALACIOS-VARGAS, J.G. Structure and composition of litter and soil Poduromorpha assemblages (Hexapoda: Entognatha: Collembola) from a topical dry forest in western Mexico. Folia Entomologica Mexicana, v.43, p.215-225, 2004.

HASEGAWA, M. The relationship between the organic matter composition of a forest floor and the structure of a soil arthropod community. European Journal of Soil Biology, v.37, p.281-284, 2001.

HAY, J.D. ; LACERDA, L.D. de. Ciclagem de nutrientes no ecossistema de restinga. In: LACERDA, L.D. de; CERQUEIRA, R.; TURCQ, B. (Ed.). Restingas: origem, estrutura, processos. Niterói: CEUFF, 1984. p.459-473.

LUDWIG, J.A.; REYNOLDS, J.F. Statistical ecology: a primer on methods and computing. New York: John Wiley \& Sons, 1988. 340p.

MCCUNE, B.; MEFFORD, M.J. PC-ORD for Windows: multivariate analysis of ecological data. Version 4.14. Gleneden Beach: MjM Software, 1999.

MENDONÇA, M.C. de; ARLÉ, R. Variação quetotáxica em Brachystomella agrosa Wray, 1953 (Collembola, Neanuridae). Boletim do Museu Nacional, Nova Série, Zoologia, v.351, p.1-9, 1992.

MENDONÇA, M.C. de; FERNANDES, L.H. A new genus of Brachystomellinae from Brazil (Collembola: Neanuridae). Boletim do Museu Nacional, Nova Série, Zoologia, v.379, p.1-7, 1997.

MIRANDA-RANGEL, A.; PALACIOS-VARGAS, J.G. Estudio comparativo de las comunidades de colémbolos edaficos de bosque de Abies religiosa y cultivo de haba (Vicia faba). Agrociencia, v.3, p.7-18, 1992. 
POZO, J. Ecological factors affecting Collembola populations. Ordination of communities. Revue d'Écologie et Biologie du Sol, v.23, p.299-311, 1986.

RODRIGUES, W.C. DivEs - diversidade de espécies: software e guia do usuário. Version 2.0. 2005. Available at: <http://www. ebras.vbweb.com.br>. Accessed on: 02 Nov. 2005.

SALMON, S.; PONGE, J.F.; VAN STRAALEN, N.M. Ionic identity of pore water influences and $\mathrm{pH}$ preference in Collembola. Soil Biology \& Biochemistry, v.34, p.1663-1667, 2002.

SILVA, J.G. da; OLIVEIRA, A.S. de. A vegetação de restinga no Município de Maricá, RJ. Acta Botânica Brasileira, v.3, p.253-272, 1989.

SILVA, J.G. da; SOMNER, G.V. A vegetação de restinga na Barra de Maricá, RJ. In: LACERDA, L.D. de; CERQUEIRA, R.; TURCQ, B. (Ed.). Restingas: origem, estrutura, processos. Niterói: CEUFF, 1984. p.217-224.

SOUSA, J.P.; GAMA, M.M. da; FERREIRA, C.S. Effects of replacing oak-woods by Eucalyptus on edaphic Collembola communities: does the size and type of plantation matter? Acta Entomológica Ibérica e Macaronésica, v.1, p.1-10, 2003.

STATSOFT. STATISTICA for Windows [Computer program manual]. Tulsa: Statsoft, 1997.
THIBAUD, J.M. Collemboles intertitiels des sables littoraux de Guyane Française (Collembola). Revue Française d'Entomologie (Nouvelle Serie), v.26, p.63-66, 2004.

THIBAUD, J.M. Contribution à la connaissance des collemboles interstitiels des sables littoraux du Vietnam. Revue Française d'Entomologie (Nouvelle Serie), v.24, p.201-210, 2002.

THIBAUD, J.M.; CHRISTIAN, E. Biodiversity of interstitial Collembola (Insecta) in sand sediments. European Journal of Soil Biology, v.33, p.123-127, 1997.

THIBAUD, J.M.; CHRISTIAN, E. Collemboles interstitiels aériens des sables littoraux méditerranéens. Annales de la Société Entomologique de France, v.25, p.71-81, 1989.

THIBAUD, J.M.; PALACIOS-VARGAS, J.G. Brazilian Collembola from littoral sand with description of Austrogastrura gen. n. and Isotomodes carioca sp. n. [Hypogastruridae; Isotomidae]. Revue Française d'Entomologie (Nouvelle Serie), v.21, p.25-31, 1999.

THIBAUD, J.M.; Z. MASSOUD. Les Collemboles des Petites Antilles. III. Neanuridae (Pseudachorutinae). Revue d'Écologie et Biologie du Sol, v.20, p.111-129, 1983.

VALLEJO, L.R.; VALLEJO, M.S. Contribuição ao estudo ecológico dos microartrópodos do "litter" na Restinga de Maricá, RJ. Revista Brasileira de Biologia, v.41, p.535-543, 1981.

Received on September 4, 2008 and accepted on June 13, 2009 